\title{
Aesthetic and Spiritual Correlations in Javanese Gamelan Music
}

There are striking similarities and intriguing connections between the tradition of gamelan music in Java and Javanese mystical traditions. A gamelan is an ensemble of gongs, metalophones, drums, bowed lute, xylophone, zither, bamboo flute, and singers. Gamelans of many different types exist in Java, Bali, and Lombok, as well as in Malaysia. Some include only a few gongs; others have up to fifty instruments. The type of ensemble that concerns us is the largest of these ensembles, the gamelan of Central Java. Its most important function is to accompany dance, theater, and ceremonial occasions, such as weddings, in both ritual and commercial settings.

The links between the musical and mystical traditions of Java have not been much noticed or examined in the scholarly literature. The focus of gamelan research has been elsewhere: on the performance styles of particular instruments or musical groups, the history of the tradition, including the effects of Westernization, analysis of mode, musical cognition, and Javanese music theory. Judith Becker, in her fascinating and suggestive Gamelan Stories: Tantrism, Islam, and Aesthetics in Central Java, does point out that vestiges of ancient mystical practices can be found in pitch names, the titles of musical pieces, and in the sacred bedhaya dance. ${ }^{1}$ These observations are symptoms, it seems to me, of more fundamental and more pervasive links between gamelan music and spirituality in Java. I contend that gamelan music mirrors and manifests a central system of thought, experience, and belief in Javanese culture: mysticism. Though waning in recent decades, mysticism has long been a focal point in Javanese culture, so it is not surprising that Java's musical system is organized, at least in part, to support, manifest, and express that system. The stated aim of music making, the structure of the music, the leadership styles, and the creation of melodies have remarkably close parallels in the Javanese mystical world. ${ }^{2}$

My analysis of the link between Javanese musical and mystical traditions centers on the concept of rasa, which is crucial to both traditions. I start with the ancient Sanskrit theory of rasa, then move to the central role of rasa in contemporary Java musical groups, followed by an analysis of Sumarsam's "inner melody" theory of Javanese music. Finally, I show that rasa is not merely an abstract construct accessible to an elite cadre of the most knowledgeable gamelan musicians: it is the basis of music making for many musicians, especially those of the older generation.

Before delving into the links between the mystical and musical traditions of Java, I need to flesh out the concept of rasa. The primary meaning is feeling. As 'feeling,' it refers to the physical senses of taste and touch and also to emotional feelings. Rasa can also mean 'meaning.' The example Clifford Geertz gives is: "rasa is applied to words in a letter, in a poem or even in a speech, to indicate the between-the-lines 'looking north and hitting south' type of allusive suggestion that is so important in Javanese communication." "3 As this example illustrates, rasa can mean the essential, often hidden, significance of something obscure. This concept of rasa points back to the first notion of rasa as feeling and taste. For the Javanese, to fathom something obscure, one has to engage all one's senses, feelings, and intuitions, as if one were tasting the essence of the thing. To use merely one's intellectual capacities is not enough. 
I. RASA IN SANSKRIT AESTHETIC THEORY AND IN SUFISM

Rasa is an integral part of two Javanese mystical traditions: Tantric Shaivism and Mahayana Buddhism on the one hand, and mystical Islam (Sufism) on the other hand.

Sanskrit aesthetic theory constitutes a key element in Java's Tantric Shaivism and Mahayana Buddhist mystical traditions. Sanskrit aesthetic theory was first articulated in the Natyasastra, the main Sanskrit treatise on dramaturgy dating somewhere between the second century and eighth century $\mathrm{CE}$, and was further developed in the tenth century by the Tantric Shaivite philosopher, Abhinavagupta, of Kashmir. ${ }^{4}$ Java and other parts of Southeast Asia were strongly impacted by Indian culture during the first millennium of this era. The products of this influence include Indian religions, mythology, and, as Laurie Sears posits, Sanskrit aesthetic theory. ${ }^{5}$

A crucial concept in Sanskrit aesthetic theory is the notion of rasa. According to this theory, the hallmark of a good drama is its ability to develop a particular rasa, which then dominates the work. ${ }^{6}$ The Natyasastra mentions eight primary rasa: the erotic (srngara), the comic (hasya), the pathetic (karuna), the furious (raudra), the heroic (vira), the terrible (bhayankara), the odious (bibhatsa), and the marvelous (adbhuta). Abhinavagupta added a ninth rasa: the santa rasa, or tranquil sentiment associated with mystical experience. The exact production of rasa is not fully explained in the Natyasastra and has thus been interpreted differently by different Indian philosophers. The Natyasastra states: "The Sentiment is produced (rasanispattih) from a combination (samyoga) of Determinants (vibhava), Consequents (anubhava), and Transitory States (vyabhicaribhava)."7 Determinants are the causes of emotion, such as elements in a drama that might bring forth old memories and rouse the emotions. The consequents are the physical effects (for example, blushing) arising due to the determinants. The vyabhicaribhava are secondary, transient emotions, such as weeping with joy. As these three elements work together, the aesthete experiences one of the eight sthayi bhava, the primary emotional states. "The welling up of this emotion causes a state of total engrossment, which concomitantly leads to the loss of ego ... The totally unhampered experience of the sthayi bhava welling up from within is rasa." 8
The rasa magnetizes the viewer, pulling her or him into the dramatic situation so that the viewer can relish the work in an almost gustatory way, experiencing it in mind and body. ${ }^{9}$ Enthralled by the rasa, the viewer is freed from her or his usual mental chatter, liberated from the ego. Masson and Patwardhan explain:

for the duration of the aesthetic experience, the normal waking "I" is suspended . . . all normal emotions are gone ... we experience sheer undifferentiated bliss ... for we have come into direct contact with the deepest recesses of our own unconscious where the memory of a primeval unity between man and the universe is still strong. Inadvertently ... we have arrived at the same inner terrain as that occupied by the mystic. ${ }^{10}$

Thus for Abhinavagupta, aesthetic enjoyment and mystical experience are intimately connected, for through works of art a person reconnects with the fundamental oneness of all things, what some may call the Absolute. But that Absolute resides within oneself. As a person fully experiences an aesthetic work, one merges with the object of contemplation, identifying completely with it, and experiences his or her pure self, or "highest Self." Masson and Patwardhan explain: "We can thus see that all of Abhinava's efforts focus on one important need: to crack the hard shell of the ' $\mathrm{I}$ ' and allow to flow out the higher Self which automatically identifies with everyone and everything around." 11 This notion of art as a tool for achieving oneness explains a seeming anomaly in this theory: the word ' $r a s a$ ' refers both to the feelings experienced by the viewers of dramatic works and to the most profound mystical awareness. For Abhinavagupta, the two are the same, for one cannot truly appreciate a work of art without achieving that mystical experience.

However, not everyone is capable of experiencing this level of aesthetic and spiritual bliss. Only a person who can transcend his or her ego, merging completely with the work of art, can do so. Such a person is called sahrdaya, "sensitive."12

Crucial to this theory of aesthetics is that the essential meaning of a work, its rasa, is never stated directly, but only suggested. This is true for two reasons, according to Abhinavagupta. First, a work that makes veiled allusions "carries far greater beauty" than one that bluntly asserts its truths. ${ }^{13}$ Second, the very act of unearthing the hidden meaning in an aesthetic work 
has spiritual value, for it "impels us to great devotion for another truth, beyond the phenomenal world." 14 The fundamental meaning of an aesthetic work is hidden, just as knowledge of ultimate reality is believed to lie deep within a person.

Several tenets in rasa theory touch on key issues of Western aesthetics. Abhinavagupta's focus on individual experience of intense emotion suggests that for him, aesthetic meaning is located in the perceiver, not the aesthetic work. For example, the rasa of pathos (karuna) resides in the aesthete and is not an inherent element of the work itself. Furthermore, for Abhinavagupta, an individual's response to a work is a product of his or her culture, for the determinants of emotion (vibhava) are, in part, culturally determined. Finally, Abhinavagupta articulates a theory about the location of the fundamental emotions within the individual. To access rasa, one must free oneself from one's ego, suggesting that the primary emotions reside in the unconscious or subconscious. ${ }^{15}$

Rasa theory resonates with some elements of Arthur Schopenhauer's philosophy. For him, life is characterized by a continuous striving and craving. People can escape from that suffering in the "quiet contemplation of the natural object actually present, whether a landscape, a tree, a mountain." 16 In this reflection, one disassociates oneself from "the principle of sufficient reason"; one "loses" oneself to such a degree that the person and the object "become one," and the person becomes a "pure, will-less, painless, timeless subject of knowledge." ${ }^{17}$ In later passages, Schopenhauer makes clear that artists have a particular ability to engage in this kind of contemplation, for he characterizes art as "the way of viewing things independent of the principle of sufficient reason." 18

Though rasa is originally a Sanskrit word, it is significant not only in Tantric Shaivite and Buddhist texts, but also in Sufi mystic contexts, and in the syncretic mystical sects that combine elements of all three religions. Indeed, all these religions share a belief in the ultimate goal of the union with the Absolute Being (or Allah in Islamic terms). According to Mark Woodward:

While this concept [rasa] owes much to the Mahayana Buddhist notion of sunyata (S.; void), it will be argued here that this and other legacies of the Hindu-Javanese past are interpreted in terms of Islamic assumptions about the mystical path and the unity (A., tawhid) of Allah. ${ }^{19}$
Both G. W. J. Drewes and Judith Becker stress that Tantric mysticism and Sufi mysticism in Java shared so many features that the transition from the Indian to the Arabic form was probably quite smooth. ${ }^{20}$

\section{RASA IN CONTEMPORARY JAVANESE SPIRITUAL CONTEXTS}

Moving toward my goal of exploring the similarities between Java's spiritual and musical traditions, I focus in this section on the central role of rasa in Javanese mystical groups. According to Clifford Geertz, rasa is the "connecting link" between the three major components of religious life: mystical practice, art, and etiquette. This is especially true for the priyayi (the aristocratic elite). The person who truly understands ultimate reality-rasa sejati-can express that understanding through gestures in dance, sounds in music, or words in poetry. ${ }^{21}$ Such a person is naturally refined (alus) in his or her outer behavior. The concept of rasa is important not only to the priyayi but to many other Javanese as well. The popularity of mysticism in Java may be judged by the presence there of several hundred mystical groups.

One of the most prominent sects is Sumarah. ${ }^{22}$ Established in the mid 1930s, Sumarah includes elements of Tantric Shaivism, Mahayana Buddhism, and Islam with indigenous mystical practices. The membership, which in 1984 was estimated at 10,000, includes individuals of all ethnic, social, and religious backgrounds. ${ }^{23}$ Since the focus in Sumarah is on individually perceived spiritual experience (though within a group setting), there is a minimum of dogma. Members meditate individually and in group meetings, led by a spiritual leader.

According to Sumarah practice, meditation begins with relaxing the body and shifting the attention from thoughts to physical sensations and to feelings. The purpose is to free oneself from the usual form of consciousness, which is believed to center on the obsessive replaying of thoughts about the future or the past. The practitioner focuses on the feelings experienced in the present: perhaps a physical sensation or an intense emotion that floats to the surface of the consciousness, a feeling that is normally hidden by the barrage of constant thoughts. As stillness and concentration deepen, one is more able to ignore the thoughts 
constantly rushing through one's head, while focusing awareness on a deeper, stiller, nonverbal part of oneself. Gradually, it is thought, the practitioner becomes aware of another level of being, termed rasa sejati, which Stange defines as "the absolute or true feeling [or] ... mystical awareness of the fundamental vibration or energy within all life." 24 Most people in Sumarah use the term 'Allah' to refer to rasa sejati, though some prefer to avoid the term as too specific. The word 'sumarah' means surrender, and refers to the process of transcending normal consciousness and becoming aware of rasa sejati.

As one frees oneself from a normal form of consciousness, according to Sumarah theory, one becomes aware that one's perception is distorted by one's own experiences and beliefs. Stange describes this process as follows. "Beyond the senses and thought perception there lies a cleaning of internalized subconscious blockages, so that gradually perception is less filtered through subjective structures." ${ }^{25}$ When this occurs, according to the members of Sumarah, one is able to perceive a fundamental truth: that all people, even all things, are essentially one.

Since in the phenomenal world, there appear to be distinctions between the material and spiritual, the Javanese identify two aspects of reality: lahir and batin. Lahir (from Arabic zahir), literally, "outer reality," consists of habits, behaviors, the material world, and surface phenomena. Batin (from Arabic batin), or "inner reality," is the inner spiritual life of an individual. Batin is accorded more value, for whereas surface forms reveal only the appearance of reality, batin is the essence. ${ }^{26}$ The two are related, for features apparent in the phenomenal world are regarded as manifestations of the inner reality.

Because of the fundamental unity of all things, lahir and batin are not really opposite, but merely different expressions of reality. They are ultimately identical. According to Javanese thought, a physically beautiful person is necessarily faultless in her or his inner spiritual being, for the exterior is a manifestation of the interior.

These notions of the fundamental identity of lahir and batin are central to the story of Seh Siti Jenar, a Sufi master of mysticism, as told in the nineteenth-century Babad Jaka Tingkir. ${ }^{27}$ Siti Jenar was executed for disseminating a secret that the wali (Islamic saints) felt should not be made public. Dissemination of that sacred knowledge was threatening to the walis' attempts to consolidate their political authority. The "secret" was the knowledge of the means for attaining spiritual empowerment, sunyata jatimurti. How does one attain spiritual empowerment? By grasping the essential oneness of all things. That understanding, called rasa in the text, is the ultimate reality, the absolute truth. One who has attained that knowledge "has grasped the ultimate of rasa/Rasa that is Reality." ${ }^{28}$ Such a person has understood that things normally seen as opposites are in fact identical: lahir and batin, spirit and matter, divine and profane, Being and Nonbeing. ${ }^{29}$

Group meditation is central to Sumarah because of the focus on unity. Absolute truth can be perceived by individuals, but can be "confirmed" only by the group, which comes to a consensus through a process of communal meditation. During periods of group division, members enter deep meditation together. Each person "attunes" himself or herself to the rasa of the group. As each one becomes intuitively aware of the feelings of the group, consensus is reached. The group is central in making manifest the underlying truth. The assumption is that the "correct decision ... is implicit in the situation." 30 The absolute truth already exists but has to be discovered by humans. Likewise, in musical terms, as we shall see later, the appropriate choice of a musical pattern is said to be "implicit" in the immediate musical context, and it is the job of the musician to discover that pattern.

\section{RASA AND GAMELAN MUSIC}

Having established the importance of rasa and mysticism in Java today, I now turn to the heart of the argument: the remarkable linkages between Javanese spiritual and musical traditions. I will argue that for many Javanese, music has a strong spiritual dimension. In both traditions, rasa is central. Furthermore, absolute truth resides beneath surface manifestations. The very structure of the music reflects this belief. Since truth is hidden, the job of the practitioner-whether a mystic or a musician-is to make manifest that spiritual or musical truth. Finally, group collaborative work is key in uncovering those truths in both traditions.

Rasa is fundamental not only to Javanese mystical practice but to Javanese notions of aesthetics as well. According to historian Laurie Sears, 
rasa strongly influenced the development of Java's most important art form: wayang kulit (shadow puppet theater), which encompasses drama, classical poetry, epic stories, and gamelan music. ${ }^{31}$ Sastrapustaka, a highly respected Javanese musician who was trained in the courts in the 1920s, paints gamelan music in terms reminiscent of Sanskrit theory. He says, "the art [of gamelan]—which is thought to be only for entertainment-is actually important for the physical (lahir) and spiritual (batin) education of all who study it in depth. Also, art is ... a device for raising the grandeur of a people's spirit." 32 For Sastrapustaka, music is a guide for spiritual development. In Sanskrit theory, drama also has this function, as aesthetic experience shades imperceptibly into mystical bliss. Sastrapustaka continues: "Indeed it is very clear that this art can only give rise to a radiance or light which is pure, if it resides within a person whose temperament is noble and refined." 33 This statement hints at the Sanskrit notion of the sahrdaya, the sensitive aesthete, for only highly spiritually developed individuals can appreciate art, according to Sastrapustaka. ${ }^{34}$ Furthermore, his exegesis of the meaning of gamelan pitch names is suggestive of Hindu/Buddhist chakra, centers of spiritual energy in the human body, as Judith Becker has argued. The chakra were focal points in body-based spiritual techniques of medieval Java. ${ }^{35}$

Sastrapustaka's comments hint at the connections between the musical and mystical traditions; the shared terminology provides tangible proof. In both cases, rasa is a crucial concept. For some gamelan musicians, it is "the key to aesthetic understanding." ${ }^{36}$ Rasa has a wide range of meanings in gamelan music. "Feeling" and "inner meaning" are two common translations. A standard means of categorizing gamelan compositions is by rasa, so that there are sad pieces, exuberant pieces, flirtatious pieces, and so forth. This notion of rasa, as the primary mood or sentiment of a work, echoes the ancient Sanskrit idea that a poem or drama must convey one primary rasa.$^{37}$ Rasa can also refer to "the ability to express or perceive feeling or inner meaning" or "intuition." 38 This notion of rasa is important for musicians who play the gamelan instruments that utilize improvisation. These musicians express the "inner meaning" or rasa of a piece by altering standardized melodic patterns or even creating new melodies to fit both the melodies played by the other musicians and the wider performance context.

One of the basic notions of rasa, common to both Sanskrit and Javanese uses of the term, is that the absolute truth resides at a fundamental level. Just as rasa sejati is sequestered deep in the batin beneath the surface manifestations of the lahir, the essence of a piece is thought by some theorists to be hidden beneath surface phenomena. Sumarsam calls this essence the lagu batin" or inner melody. ${ }^{39}$ This melody is inner not only because it represents the heart of the piece but also because it exists, in complete form, only in the minds of the musicians. It can never be played by just one instrument, but only by the combination of instruments working together. The inner melody that musicians hear inside their heads, then, is a composite-bits of melodies of a variety of instruments. That inner melody represents the essence of the piece, the batin, while the melodies actually played on different instruments are akin to the lahir, or surface manifestations.

I am making the analogy between the spiritual concept of batin and the musical concept of inner melody to point out the shared discourse in the aesthetic and spiritual traditions in Java. The way that many Javanese talk about music and mystical experiences suggests that for them, the experiences of listening to gamelan music and achieving contact with the absolute truth may be akin. In describing both musical and mystical experiences, the Javanese focus on the inner meaning. For example, Sumarsam says:

In a gamelan rehearsal or performance, each musician relates the part he plays to the melodies played on the other instruments. This practice is often employed during the learning period. At the same time, it also allows the musicians to gradually absorb the underlying feeling of gendhing (composition) as inspired by the melody of the whole ensemble. This underlying feeling of gendhing is the essence of Javanese gamelan melody-the inner melody as felt by the musicians. ${ }^{40}$

This statement is resonant with Clifford Geertz's informant who stated that the essence of a person resides in the center of four concentric circles-representing (from outer to inner) the body, the five senses, the conscious will, and the unconscious origin of desires. In the center is the essence, which is "fixed and unchanging, 
it is always good, and it is that which judges and directs our will, or ought to." 41 The progression from outer manifestation to inner absolute reality that the initiate traverses during meditation is described in Sumarah terminology as follows.

"Feeling" in its turn may in the first instance mean awareness of physical sensation within the body, but that grosslevel rasa becomes progressively more subtle-it shades through inner physical sensation into awareness of the emotions and ultimately into rasa sejati, the absolute or true feeling which is itself mystical awareness of the fundamental vibration or energy within all life. ${ }^{42}$

Common to both the inner melody and the absolute truth is an element of concealment. The inner melody is never fully sounded by any one instrument. In Sanskrit aesthetic theory, the rasa or true meaning of a work cannot be directly stated, but only suggested. J. Gonda, scholar of Javanese literature, points out that in old Javanese texts, the word rasa "often served to translate the Arabic sirr 'secret, mystery,' which refers to the most ... hidden ... elements in the human heart in which God is said to reside." 43

This element of concealment pervades other aspects of both gamelan music and Javanese literature. ${ }^{44}$ Clara Brakel notes that the texts of the sacred srimpi and bedhaya dances "are usually wrapped in mystery and symbolizing-indicating the 'magical loadedness' of the situations in which they serve: well-known word-forms are either altered intentionally or replaced by strange, archaic, and foreign sounds." ${ }^{45}$ Certain Javanese pieces and Balinese musical instruments are never performed in public. In describing the spiritual power of four unusual gendhing, the famous court musician Warsadiningrat states, "our forefathers kept the knowledge of these gendhing strictly to themselves, for use in secret. Only a few people had the good fortune to be chosen to receive this knowledge. ${ }^{46}$ Sastrapustaka titled his article on gamelan music "Wedha Pradangga Kawedhar" ("Knowledge of Gamelan Revealed"). The first section is called "The Cryptic Literature (Sastra Sinandi) Concealed in the Tones of the Gamelan." $" 47$

Because the underlying truth and the inner melody are hidden, it is the task of the practitioner to uncover that truth or to make manifest the inner melody. The process of articulating the inner melody is analogous to the search that Sumarah members undertake in their attempt to find rasa sejati. For them, solving a problem is not a matter of creating a solution but of discovering the truth, which is thought to be implicit in the situation. Similarly, the gamelan musician chooses melodic formulas, called cengkok, to fit the particular musical situation. Some of those formulas are standard ones, heard in many pieces, but many are contrived for the situation, as variations of the standard ones. Whereas a Western musicologist might regard this task as creating, the Javanese characterize it as golek, or searching. R. Anderson Sutton points out that searching differs from innovative creation in that searching implies that the object sought already exists. ${ }^{48}$

Collaboration is a key element in uncovering both the absolute truth and the inner melody. Just as in Sumarah where uncovering the absolute truth is the responsibility of the group, unveiling the inner melody requires the energies of everyone in the ensemble. Although it is theoretically possible for one musician to play his interpretation of the inner melody on a single instrument, no one instrument can play it without breaking rules of style and range. Furthermore, other musicians would not agree with his conception in every detail. The inner melody can be realized only by all the instruments of the ensemble playing the piece together, for the inner melody is a compilation of interpretations of all the musicians present. Although Supanggah's view of the melodic essence of a piece differs in crucial ways from Sumarsam's, Supanggah, like Sumarsam, emphasizes the combinational and holistic aspects of the implicit, unplayed melody. He states: "It is the sound produced by ... the entire ensemble that is called the gendhing or piece. The gendhing exists only in the moment of performance." ${ }^{49}$ Because of this focus on group rather than individual musical production, there is no tradition of virtuoso solo performers. Gitosaprodjo comments: "The playing of a gamelan group must be smooth and harmonious. The situation must be avoided in which one person tries to show off his expertise to the disadvantage of others ... It must be remembered that gamelan playing is a collective activity." ${ }^{50}$ Likewise, in Javanese mystical practice, absolute truth (rasa sejati or hakiki) is manifested only through group experience. According to Stange, "it is understood that Hakiki is only confirmed when it 'meshes' 
with collected experience during the attunement and achieved through group meditation." ${ }^{51}$ People are not encouraged to meditate on their own. ${ }^{52}$

The form that musical leadership takes in gamelan music is reminiscent of the leadership style in the mystical groups. Members of Sumarah stress that the pamong, or guide, is not a teacher. Through meditation, the pamong becomes intuitively aware of the inner states of the individuals in the group and makes suggestions about their practice based on that knowledge. However, the pamong frequently reminds people not to use his or her suggestions without testing them internally for their applicability. ${ }^{53}$ If members of the group feel that the pamong is not making intuitive contact with them, they replace him or her. Likewise, in gamelan music, leadership is shared and diffuse. There is no conductor. In playing a piece, musicians both follow their own conceptions of the inner melody and listen to the suggestions from other instruments that express it. Sometimes they even ignore it. According to Sutton, unbending fidelity to the inner melody (which he calls lagu following his teacher Suhardi) is not aesthetically appropriate. Instead, he says, "instruments should exhibit some aspects of the lagu and some pleasing deviations from it." ${ }^{54}$ Like Sumarah, the gamelan group has its guide: the rebab, a two-stringed bowed lute. Called the pamurba jatmaka or "that which controls the soul," the rebab is thought to express the main emotion, or rasa, of a piece. ${ }^{55}$ However, the absence of the rebab is not critical: other instruments can take over its role as guide.

All of this suggests a dynamic relationship between individuality and consensus in both the Sumarah group and in the gamelan. Although individual meditators are encouraged to test the validity of suggestions from the pamong within themselves, members of a group nonetheless meditate together in order to reach a consensus. The instruments in the gamelan are highly individual in timbre, range, rhythmic density, and style, and the aim in ensemble playing is not a fusion of sounds, but the capacity for each instrument to retain its individuality in a group. Yet, the instruments of the gamelan sound the same pitches at important structural points.

Calmness, harmoniousness, and balance are important features of both Javanese mysticism and gamelan music. Masson and Patwardhan speak of "the unprecedented mental and emotional calm" achieved in meditation. ${ }^{56}$ James L. Peacock describes the mystical experience as follows.

Discovery of the rasa is rewarded by an ecstasy comparable to orgasm ... Afterward, one feels at peace and in balance ... By unifying his inner being, he automatically harmonizes his social relations as well. The initiate is now prepared to cope calmly with the struggles of life, and like Arjuna, to carry out his duties with detachment. In fact some of the sects believe that through meditation ... all the Indonesian groups - the entire world-will be brought into harmony. ${ }^{57}$

Certainly not all gamelan pieces are uniformly calm. Nonetheless, it is striking how much of the music does seem to strive for balance and serenity. Musical climaxes are frequently muted. Sutton notes that some melodic patterns suggest the final pitch of a melody several beats before the other instruments arrive at the point of coincidence, "thereby diminishing any jarring sense of surprise, and hence any threat to the equilibrium of the players and listeners." ${ }^{58}$ Because of the deeply calming and integrating effect of gamelan music, Javanese occasionally play on a single gamelan instrument at night as a form of meditation. $^{59}$

I have shown how gamelan music and mysticism in Java share many elements of discourse and experience. The Sanskrit scholar says that a work of art can cause transcendent states; some Javanese musicians feel that gamelan music can be spiritually uplifting. The Sanskrit scholar says that only the sensitive aesthete can appreciate a work of art; some Javanese musicians claim that only the spiritually pure can truly understand gamelan music. For Javanese meditators, "ultimate reality" is not overt; in gamelan music, the inner melody is never stated, only suggested. Members of Sumarah believe that solving a problem involves discovering the truth, which is implicit in the situation; gamelan musicians state that all melodic formulas, even ones newly created for the situation, are inherently a part of the music. The Sumarah leader does not control the members of his or her group, but instead guides them; similarly, the gamelan has no conductor in the Western sense. The Javanese mystic emphasizes calmness, balance, and communal experience; so does the Javanese musician. 
IV. SECRECY IN MYSTICAL AND MUSICAL TRADITIONS IN JAVA

I suggest that the mystical underpinnings of the gamelan tradition have not been discussed in detail by scholars of Javanese music because of the element of concealment associated with mystical traditions. As Warsadiningrat's and Sastrapustaka's statements imply, playing certain gendhing (musical pieces) and discussing the "cryptic" associations and meanings of gamelan music were limited to a select few in times past. Except for giving a few tantalizing allusions to the hidden spiritual meaning of gamelan music, Warsadiningrat consciously avoided direct discussion of the subject in his massive work. He explained his reasons as follows.

Writings on the history or story of gamelan included in this book only describe krawitan [the art of gamelan music]; they do not explain the meanings or purposes of gamelan or gendhing. Those things this book does not explain because the person who truly understands the meanings and purposes of gamelan and gendhing must supply his own interpretation. ${ }^{60}$

His last sentence refers to a reason why the spiritual purposes are not discussed-because coming to an understanding of the inner meaning of gamelan music is an individual matter, just as gaining access to one's inner being is an individual matter. In either case, the individual must embark on an intense inner journey, partly if not wholly spiritual in nature. ${ }^{61}$ This is not to say that individuals achieve these understandings by working entirely alone; in fact, in both the mystical and musical settings, these understandings are best achieved in a group context. The doctrines of Sumarah stress these points about secrecy and individuality: that mystical traditions are secret not because mystics want to exclude others but because the task of uncovering the truth is the responsibility of the individual.

From the external vantage point it is often assumed that mystics employ code languages laden with secret meanings designed to exclude outsiders. Even when this is the case it has little to do with the basis of the esoteric as gnosis is seen by mystics. In terms of mystical principles gnosis is fundamentally dependent on an internal journey through meditation or other "opening" procedures.
The "secrets" of mysticism lie within rather than being held by other people. Normal consciousness systematically blocks individual awareness; the secret is something which, in mystical terms, we keep from ourselves. In fact most traditions hold that the gnosis sought by mystics is readily available to anyone whose internal receptivity allows it, to anyone who genuinely "wants" it and regardless of whether they relate to a "mystical" movement. ${ }^{62}$

Stange's last sentence clarifies what may seem like a paradox to some. On the one hand, gamelan music is not considered esoteric, abstruse, or in any way inaccessible to the ordinary person and yet, on the other hand, the music is associated with traditions of mysticism. But this is not a paradox, for in the Sumarah view, each individual has access to "ultimate reality," though access to it is hidden by his own limitations. Likewise, in terms of music, each person can establish for himself the "meaning or purposes" of gamelan music, as Warsadiningrat has said.

\section{RASA IN THE MUSIC OF SOLO FEMALE SINGERS}

Lest the reader conclude that the concept of rasa and the spiritual dimension of gamelan music are limited to an elite circle of Javanese gamelan theoreticians whose venerable status allows them access to secret mystical knowledge, I end with a discussion of the central position of rasa among Javanese gamelan performers. I will use pesindhen, solo female singers who perform with the gamelan, as an example.

Nyi Gitotenoyo (born 1919; died around 1995) was one of the most influential pesindhen of her generation. She was a pivotal figure in the history of solo female singing in the central Javanese city of Solo, for she popularized the style associated with the main palace, the kraton, the style that prevails even today. ${ }^{63}$ Several younger singers told me that they modeled their singing after Nyi Gitotenoyo's.

In a personal communication in 1992, Gitotenoyo stressed to me the central role of rasa in her music making. "I must say that I, well, pesindhen in the past, did not understand writing and did not go to school. So, we could only practice ... rasa. With rasa, wherever the music went, I could enter in. I could sing just by listening to the 
sound of the gamelan." The understanding of rasa among pesindhen in Nyi Gitotenoyo's generation allowed them to sing pieces they had never even heard before, though they could not read notation.

Nyi Gitotenoyo explained that pesindhen of her time were trained to discover what they should sing by listening to the melodies played on the softer sounding instruments, particularly the $r e$ $b a b$, the bowed instrument. In her words, pesindhen "sang by using rasa"; for they felt or sensed where the melody was going before it went there. Embedded in the rebab melody are clues about the identity of the goal tone for the next phrase. The pesindhen should sing a cengkok, or melodic formula, whose last pitch matches the pitch of the goal tone. As soon as the rebab melody hints what the next goal tone is, the pesindhen chooses a cengkok.

Nyi Gitotenoyo told me that to deepen her engagement with the music, she closed her eyes when she sang. Her voluntary sightlessness did not separate her from her fellow musicians, but intensified her awareness of their veiled musical suggestions. The image of Nyi Gitotenoyo immersing herself in musical sounds and interweaving her cengkok with them is strikingly akin to the subtle harmonizing of individual feelings to the rasa of the group in Sumarah meditations. In both cases, practitioners direct their inner reception to the rasa of the group so that their contributions could be attuned to that communal rasa or to that collective musical expression.

The spiritual dimension in Nyi Gitotenoyo's singing is also evident in her stated focus on starting her melodic patterns approximately when the instruments begin theirs. This allowed her to sing her patterns slowly, stretching them out before finally resting on the goal tone. Most pesindhen nowadays start their cengkok so late that have to rush through them to end at the appropriate time. She told me proudly that another musician had said of her singing: "Singing like that can make a person feel calm." According to her most prominent student, her deliberately slow style creates a feeling of sumeleh. "Sumeleh is a good feeling, like surrendering all problems to God, a feeling of tranquility." ${ }^{64}$ Again, it is noteworthy that the language of spirituality has been invoked to describe a musical phenomenon.

I am not suggesting that Nyi Gitotneoyo was consciously using her singing to communicate spiritual feelings (though she may have), but that her stated musical goals are strikingly resonant with Javanese spiritual practices. Those goals are discovering the hidden inner truth (rasa) and working collaboratively with others to create harmoniousness and tranquility. ${ }^{65}$

My main point in this paper has been to show the striking similarities and remarkable connections between the musical and mystical traditions of Java. Perhaps for some Javanese, especially the older generation, the aesthetic and spiritual experiences are inseparable, as they seem to have been for the early twentieth-century nationalist, Raden Ajeng Kartini, who described her feelings listening to gamelan music: "And my soul soars with the murmuring pure silver tones on high, on high, to the isles of blue light, to the fleecy clouds, and to the shining stars-deep low tones are rising now and the music leads me through dark dales, down steep ravines, through somber woods on into dense wildernesses, and my soul shivers and trembles within me with anguish and pain and sorrow." 66

The strong link between musical and mystical traditions in Java that I have suggested throughout this paper is shifting, especially among young pesindhen. They no longer talk about rasa as crucial to their music. However, instrumental musicians still do regard rasa as the centerpiece of their musical experience. True, the explicit spiritual associations of rasa have receded, to be replaced by more worldly interpretation of the word as feeling, as Marc Benamou has noted. ${ }^{67} \mathrm{I}$ speculate that the spiritual links are still there, just below the surface, and those links are part of the deep attraction many Javanese musicians feel for their music. The Javanese term, 'lango,' which is frequently associated with gamelan music, captures best the Javanese sense of the "spiritual." Echoing Abhinavagupta, Zoetmulder says of lango: "It is a kind of swooning sensation, in which the subject is completely absorbed by and becomes lost in its object, the appeal of which is so overwhelming that everything else sinks into nothingness and oblivion." It seems to me that emotions of this kindwhich we can term rasa-are a prominent feature of the passion for gamelan music of many people in Java. Many musicians play gamelan music all night several times a week, even when there is no audience and no remuneration. Entranced by beautiful pesindhen and copious alcohol, these musicians seem to be surrendering themselves completely to the scene, totally immersed in lango, a luscious 
feast of sensuality, pleasure, and mystical/musical bliss.

\section{SUSAN PRATT WALTON \\ University of Michigan \\ Ann Arbor, MI 48104, USA}

INTERNET: swalton@umich.edu

1. Judith Becker, Gamelan Stories: Tantrism, Islam, and Aesthetics in Central Java (Arizona State University, 1993).

2. Mangkunegara VII explores the mystical meaning of the wayang kulit (shadow puppet theater) and touches briefly on the link between gamelan music and mysticism. See "On the Wayang Kulit (Purwa) and Its Symbolic and Mystical Elements," in Data Paper Cornell University Southeast Asia Program No. 27, trans. Claire Holt (Southeast Asia Program, Dept. of Far Eastern Studies, Cornell University, 1957), original text published in Djawa xiii (1933). See also Benedictus Suharto, Dance Power: The Concept of Mataya in Yogyakarta Dance (Bandung: Sastrataya, Masyarakat Seni Pertunjukan Indonesia, 1998).

3. Clifford Geertz, The Religion of Java (University of Chicago Press, 1976, first printed 1960), p. 238.

4. Bharata Muni, The Natyasastra: A Treatise on Hindu Dramaturgy and Histrionics Ascribed to Bharata Muni, trans. Manomohan Ghosh (Calcutta: The Asiatic Society, 1950); Laurie Jo Sears, Text and Performance in Javanese Shadow Theatre: Changing Authorities in an Oral Tradition (Ph.D. dissertation, University of Wisconsin at Madison, 1986), p. 25.

5. Sears, Text and Performance, pp. 24-25.

6. Sears, Text and Performance, p. 35.

7. Manomohan Ghosh, The Natyasastra of Bharata Muni (Calcutta: The Asiatic Society, 1950), p. 105, as quoted in Sears, Text and Performance, pp. 35-36.

8. Stephen Slawek, "Engrossed Minds, Embodied Moods and Liberated Spirits in Two Musical Traditions of India," Bansuri 13 (1996): 31-35, quote is from p. 35.

9. I use feminine pronouns to indicate that women were probably not excluded from aesthetic experience in Abhinavagupta's time. Stephen Slawek points out (in personal communication) that the word for an individual who experiences rasa, 'rasik,' is gender neutral and that numerous sculptures from pre-Islamic times and paintings from the Mughal period depict women playing musical instruments. He concludes, "it would appear that women were viewed as capable of creating an aesthetic experience."

10. J. L. Masson and M. V. Patwardhan, Santarasa and Abhinavagupta's Philosophy of Aesthetics (Poona: Bhandarkar Oriental Research Institute, 1969), pp. vii-viii.

11. Masson and Patwardhan, Santarasa, p. 89.

12. Masson and Patwardhan, Santarasa, pp. 49-50.

13. Masson and Patwardhan, Santarasa, p. 108.

14. Masson and Patwardhan, Santarasa, p. 107.

15. Slawek, "Engrossed Minds," pp. 33-35.

16. Arthur Schopenhauer, The World as Will and Idea (Die Welt als Wille und Vorstellung), trans. R. B. Haldane and J. Kemp (London: Routledge and Kegan Hall Broadway House, 1964), Vol. I, p. 231.
17. Ibid.

18. Schopenhauer, The World as Will and Idea, p. 239.

19. Mark R. Woodward, Islam in Java: Normative Piety and Mysticism in the Sultanate of Yogyakarta (The University of Arizona Press, 1989), p. 68.

20. G. W. J. Drewes, "Indonesia: Mysticism and Activism," in Unity and Variety in Muslim Civilization, ed. Gustave E. von Grunebaum (University of Chicago Press, 1967), p. 287; Becker, Gamelan Stories, p. 3. As rasa moved from ancient India to Java, it changed. Javanese aesthetic theory conflates rasa and the various forms of bhava, referring to both as rasa.

21. Clifford Geertz, The Religion of Java (University of Chicago Press, 1976, first printed 1960), pp. 238-239.

22. Paul Denison Stange, The Sumarah Movement in Javanese Mysticism (Ph.D. dissertation, University of Wisconsin at Madison, 1980); David Howe, Sumarah: A Study of the Art of Living (Ph.D. dissertation, University of North Carolina at Chapel Hill, 1980).

23. Paul Denison Stange, "The Logic of Rasa in Java," Indonesia 38 (1984): 116-121, quote is from p. 116.

24. Stange "The Logic of Rasa," p. 119.

25. Stange, "The Logic of Rasa," p. 121.

26. Howe, "Sumarah," p. 116.

27. See the translation by Nancy K. Florida, Writing the Past, Inscribing the Future: History as Prophecy in Colonial Java (Duke University Press, 1995), p. 78.

28. Florida, Writing the Past, p. 190.

29. Florida, Writing the Past, p. 361.

30. Stange, "The Logic of Rasa," p. 123.

31. Sears, Text and Performance, pp. 19-35.

32. Sastrapustaka, "Wedha Pradangga Kawedhar" ("Knowledge of Gamelan Revealed"), in Karawitan: Source Readings in Javanese Gamelan and Vocal Music, ed. Judith Becker and Alan Feinstein; trans. R. Anderson Sutton (Ann Arbor: Center for South and Southeast Asian Studies, 1984), Vol. 1, p. 310.

33. Sastrapustaka, "Wedha Pradangga Kawedhar," p. 310 .

34. Why would gamelan be necessary as an aid to spiritual development if people were already noble and refined? In Javanese thought, gamelan can enhance spiritual development, but only for people who already have the seed of nobility and refinement in them.

35. Becker, Gamelan Stories.

36. Marc Benamou, Rasa in Javanese Musical Aesthetics (Ph.D. dissertation, University of Michigan, 1998), p. 63.

37. This is generally true, but some pieces do mix rasa either sequentially or simultaneously. See Benamou, Rasa in Javanese Musical Aesthetics, p. 141.

38. Benamou, Rasa in Javanese Musical Aesthetics, p. 63.

39. Sumarsam, "Inner Melody in Javanese Music," in Karawitan: Source Readings in Javanese Gamelan and Vocal Music, ed. Judith Becker and Alan Feinstein (Ann Arbor: Center for South and Southeast Asian Studies, 1984), Vol. 1. Two other Javanese theorists, Supanggah and Suhardi, have articulated slightly different conceptions of this phenomenon. Calling these melodies "implicit" or "unplayed" melodies, Marc Perlman discusses all three theories in Unplayed Melodies: Javanese Gamelan and the Genesis of Music Theory (University of California Press, 2004). See also Perlman "The Social Meanings of Modal Practices: Status, Gender, History and Pathet in Central Javanese Music," Ethnomusicology 42 (1998): 45-80. 
40. Sumarsam, "Inner Melody," p. 303.

41. Geertz, The Religion of Java, p. 315

42. Stange, "The Logic of Rasa, p. 119.

43. J. Gonda, Sanskrit in Indonesia, 2nd ed. (New Delhi: International Academy of Indian Culture, 1973), p. 256, as quoted in Stange, "The Logic of Rasa," p. 127.

44. The Javanese even have a word for this kind of deliberate concealment: semu. See Florida, Writing the Past, p. 275. She defines it as "the merely glimpsed perceptible dimension of the concealed."

45. Clara Brakel, "Traditional Javanese Poetry and the Problem of Interpretation," Indonesia Circle 26 (1981): 1324, quote from p. 21.

46. R. T. Warsadiningrat (R. Ng. Prjapangrawit), "Wedha Pradangga," in Karawitan: Source Readings in Javanese Music, ed. Judith Becker; trans. Susan Pratt Walton (Ann Arbor: Center for South and Southeast Asian Studies, 1987), Vol. 2, p. 65.

47. Sastrapustaka, "Wedha Pradangga Kawedhar," pp. 305-309.

48. Sutton, Variation in Javanese Gamelan Music: Dynamics of a Steady State, Monograph Series on Southeast Asia, Special Report No. 28 (Center for Southeast Asian Studies, Northern Illinois University, 1998), p. 199.

49. See Rahayu Supanggah, "Balungan," Balungan 3 (1988): 4 (trans. Marc Perlman).

50. Sulaiman Gitosaprodjo, "Ichtisar Teori Gamelan dan Teknik Menabuh Gamelan," in Karawitan: Source Readings in Javanese Gamelan and Vocal Music, ed. Judith Becker and
Alan Feinstein; trans. Judith Becker (Ann Arbor: Center for South and Southeast Asian Studies, 1984), Vol. 1, p. 384.

51. Stange, "The Logic of Rasa," p. 123.

52. Geertz, The Religion of Java, p. 309.

53. Stange, "The Logic of Rasa," pp. 117-118.

54. Sutton, The Javanese Gambang and Its Music (unpublished masters thesis, University of Hawaii, 1975) p. 207.

55. Sastrapustaka, "Wedha Pradangga Kawedhar," p. 315.

56. Masson and Patwardhan, Santarasa, p. vii.

57. James L. Peacock, Indonesia: An Anthropological Perspective (Pacific Palisades, CA: Goodyear Publishing Co., 1973), p. 149.

58. Sutton, Variation in Javanese Gamelan Music, p. 120.

59. Geertz, The Religion of Java, p. 289.

60. Warsadiningrat, "Wedha Pradangga," p. 31.

61. In contrast, most Western theorists do not hold that appreciating art involves a spiritual journey.

62. Stange, "The Sumarah Movement," p. 10.

63. The crucial position that Nyi Gitotenoyo holds in the history of classical Javanese singing was first pointed out to me by Alexander Dea (personal communication).

64. Supadmi, personal communication, 1992.

65 . This is not to deny that occasionally agonistic elements enter into gamelan playing.

66. Raden Adjeng Kartini, Letters of a Javanese Princess (New York: W. W. Norton, 1964), p. 50.

67. Benamou, Rasa in Javanese Musical Aesthetics, pp. 78-79. 